\title{
WeEd Control Under InTEgRated NUTRIENT MANAGEMENT Systems in Faba Bean (Vicia faba) Production in Egypt ${ }^{1}$
}

\author{
Controle de Plantas Daninhas sob Sistemas de Manejo Integrado em Feijão de fava \\ (Vicia faba) no Egito
}

\author{
EL-METWALLY, I.M. ${ }^{2}$ and ABDELHAMID, M.T. ${ }^{2}$
}

\begin{abstract}
Two field experiments were conducted in two successive seasons, 2005/2006 and 2006/2007, to determine whether management can improve faba bean competitiveness with weeds, thus helping to achieve its yield potential. The experiment included five treatments, composed of organic and mineral fertilizers, alone and mixed at different rates, along with a control and six weed control treatments, including oxadiargyl, prometryn, hand hoeing treatments alone or mixed with the herbicides, and a nonweeded treatment (control). The herbicide treatments were not superior to the two hand-hoeing treatments. Using compost favored growth and yield of faba bean more than of weeds. Adding fertilizer also improved most yield parameters. Application of compost alone or combined with 50 or $100 \%$ of the recommended NPK rate improved faba bean growth in terms of net assimilation rate, specific leaf area, and leaf weight ratio as components of relative growth rate. This improvement in growth resulted in increase of seed yield, yield components and protein of faba bean. Faba bean yield performance improved under interactive fertilizer effects and weed control treatments as growth improved, as a result of nutrient release from fertilizers and weed control.
\end{abstract}

Keywords: Faba bean, integrated nutrient management system, integrated weed management.

\begin{abstract}
RESUMO - Dois experimentos em condições de campo foram conduzidos em duas épocas sucessivas - 2005/2006 e 2006/2007 - para determinar se o manejo pode melhorar a competitividade do feijão-fava contra plantas daninhas e contribuir para um maior potencial de produção. Os experimentos incluíram cinco tratamentos, compostos de: fertilizantes orgânicos e minerais, isoladamente ou em mistura em diferentes doses, além do tratamento controle, e seis tratamentos de controle de plantas daninhas, incluindo tratamentos usando oxadiargyl, prometryn, manualmente ou misturados com os herbicidas e um tratamento sem plantas daninhas (controle). Os tratamentos com os herbicidas não foram superiores aos dois tratamentos manuais (hand hoeing). O uso de composto favoreceu o crescimento e rendimento da fava mais que os das plantas daninhas. A adição de fertilizantes também aumentou a maioria dos parâmetros de rendimento. A aplicação do composto isoladamente ou em combinação com 50 ou $100 \%$ da dose recomendada de NPK aumentou a taxa de assimilação liquida do feijão-fava, sua área foliar específica e a razão folha-peso, como componentes da taxa de crescimento relativo. O aumento do crescimento resultou em aumento do rendimento das sementes, dos componentes de rendimento e da proteína do feijão de fava. O desempenho do rendimento do feijão de fava aumentou sob efeitos interativos de tratamentos com fertilizante e de controle de plantas daninhas à medida que o crescimento aumentou, como resultado da liberação de nutrientes dos fertilizantes e controle dessas plantas.
\end{abstract}

Palavras-chave: feijão-fava, sistema integrado de manejo de nutrientes, manejo integrado de plantas daninhas.

1 Recebido para publicação em 13.3.2008 e na forma revisada em 30.7.2008.

2 National Research Centre, Botany Department, Dokki, Cairo, Egypt

* Corresponding author, <magdi.abdelhamid@yahoo.com>. 


\section{INTRODUCTION}

The growing need for sustainable agriculture has led to a renewed interest in recycling of crop residues and other organic materials as sources of soil organic matter and plant nutrients in restoring soil fertility and sustaining crop productivity (Phongpan \& Mosier, 2003). The input of nutrients as either fertilizers or manures had a great effect on soil productivity as measured by crop yields. Manure-treated soils had higher contents of organic matter and number of micro-fauna than fertilized soils, as well as higher levels of $\mathrm{P}, \mathrm{K}, \mathrm{Ca}$ and $\mathrm{Mg}$ in top soils and nitrate $\mathrm{N}$, $\mathrm{Ca}$ and $\mathrm{Mg}$ in sub-soils (Edmeades, 2003).

The addition of organic fertilizer to the soil improves its chemical and physical properties, reducing $\mathrm{pH}$ and $\mathrm{EC}$, increasing soil organic matter content and offering the nutrient elements for growing crops (Saad, 1999). Nitrogen, phosphorus, and potassium are major elements required for physical mechanisms of plant growth. Mixing organic with inorganic fertilizers had a great effect on productivity, with the balanced nutrient composition of the mixed fertilizers being a key factor in deciding the effectiveness of the mineral fertilizer in improving growth and yield of bean plants (Hamail et al., 1996).

Mahmoud et al. (2004) reported that application of organic manures at rates of 4.8$7.1 \mathrm{t} \mathrm{ha}^{-1}$ equal to $40-60 \mathrm{~kg} \mathrm{ha}^{-1} \mathrm{~N}$ enhanced faba bean growth. They also found that organic fertilizer alone or mixed with chemical fertilizer led to higher total pod yield and of its components, compared with chemical nitrogen fertilizer alone.

Faba bean (Vicia faba) is the most important seed legume in Egypt. It is an important source of protein for humans, especially low income populations. In addition, faba bean plants improve soil fertility by providing a substantial input of $\mathrm{N}_{2}$ fixation. The government encourages the production of new improved faba bean cultivars and application of high productivity cultivation methods.

Weeds are considered a major problem in bean crops causing great losses in seed yield due to direct weed-plant be competion for light, moisture and soil nutrients. Reduced faba bean yield at harvest due to weed infestation reached 29.1-33.6\% (Fernandes, 1989). Weed control is one of the essential cultural practices for increasing faba bean yield and improving its quality. Hand hoeing treatment in faba bean fields is the most widespread method of weed control, resulting in good control of weeds. (Soliman et al., 1998; Metwally, 2002; Saad E1-din, 2003; Sharara et al., 2005). Using chemical compounds for weed control requires information in order to obtain the best results. The use of herbicides in faba bean production is increasing dramatically due to their efficiency and reliability in controlling weeds. Numerous herbicides were successfully used for controlling weeds in faba bean, with Igran (terbutryn), Fusilade (fluazifop-butyl), Basagran (bentazon), Gezagard (prometryn), Amex (butralin) and Topstar (oxadiargyl) being the most prominent. Gezagard (prometryn) was used as pre-emergence herbicide in the control of a wide range of broad and narrowleaved weeds in legumes (Singh \& Wright, 2002). Some researchers have reported increased growth characters, yield and yield attributes of faba bean plants when prometryn was applied (Sha et al., 2004; Singh \& Jolly, 2004).

Oxadiargyl, a new pre-emergence herbicide, has been developed primarily for the control of broadleaved weeds and grasses in rice and sugarcane. In addition, extensive experiments in Europe (France, Italy and Spain) and Israel have shown that $300-$ $400 \mathrm{~g} \mathrm{ha}^{-1}$ of Oxadiargyl are well-tolerated by sunflower and transplanted vegetables when applied in pre-emergence or pre-transplanting (Tracchi et al., 1997). Oxadiargyl is an active pre-emergence herbicide applied on both annual monocotyledons and dicotyledons, as the product acts at germination as the new shoots come in contact with treated soil particles (Dickmann et al., 1997). Tracchi et al. (1998) and Nikolova \& Baeva (2000) reported that oxadiargyl was highly effective against annual grass and broadleaved weeds grown in some crops (sunflower, rice, faba bean, and soybean) and some vegetables (tomato, artichoke, cabbage, pepper, onion and celery). 
This work was carried out to study the effect of fertilizer and some weed control treatments on growth, physiological characters, yield and yield attributes of faba bean as well as its associated weed growth.

\section{MATERIALS AND METHODS}

Two field experiments were carried out during 2005/2006 and 2006/2007 growing seasons at the Agricultural Experimental Station of the National Research Centre at Shalaqan (Qalyubiyah Governorate), Egypt (30.19 N, 31.16 E). The soil texture was clay loam with medium fertility, containing $1.75 \%$ organic matter and $\mathrm{pH} 7.8$. Experiments were laid out in a split-plot design with four replicates. The main plots were devoted to the five fertilizer treatments, mainly, (1) compost, (2) compost $+100 \%$ NPK, (3) compost $+50 \%$ NPK, (4) $100 \%$ NPK and (5) unfertilized (control). Compost was added at the rate of $10 \mathrm{t} \mathrm{ha}^{1}$. NPK indicates the recommended dose of chemical fertilizers (N, $\mathrm{P}$ and $\mathrm{K}$ ) for faba bean production in this area, i.e., $36 \mathrm{~kg} \mathrm{ha}^{-1} \mathrm{~N}+72 \mathrm{~kg} \mathrm{ha}^{-1} \mathrm{P}_{2} \mathrm{O}_{5}+$ $57 \mathrm{~kg} \mathrm{ha}^{-1} \mathrm{~K}_{2} \mathrm{O}$. Control indicates that neither compost nor chemical fertilizers were applied.

\section{The sub-plots included six weed control treatments as follows:}

1- Oxadiargyl, commercially known as Topstar, sprayed at pre-emergence at the rate of $600 \mathrm{~g} \mathrm{ha}^{-1}$ (480 $\mathrm{g} \mathrm{ha}^{-1}$ active principle) after planting and before irrigation.

2- Prometryn, commercially known as Gezagard, sprayed at pre-emergence at the rate of $3 \mathrm{~L} \mathrm{ha}^{-1}\left(1.5 \mathrm{~L} \mathrm{ha}^{-1}\right.$ active principle) after planting and before irrigation.

3- Oxadiargyl at the rate of $400 \mathrm{~g} \mathrm{ha}^{-1}$ (320 $\mathrm{g} \mathrm{ha}^{-1}$ active principle) + one hand hoeing at 21 days after sowing (DAS).

4- Prometryn at the rate of $2 \mathrm{~L} \mathrm{ha}^{-1}\left(1 \mathrm{~L} \mathrm{ha}^{-1}\right.$ active principle) + one hand hoeing at 21 DAS.

5- Two hand hoeings at 21 and 35 DAS.

6- Non-weeded (control).

The organic composts used in these experiments were supplied by an Egyptian company for solid waste recycling (ECSWR), Cairo, Egypt. The organic compost produced through burying wastes from agricultural residues, (e.g. Obur Market fruit and vegetable residues) characterized by a high content of organic material (vegetable, fruit, banana tree leaf, vegetable and fruit residues). Some compost characteristics were as follows: $30 \%$ moisture content; $7.5 \mathrm{pH} ; 3.5 \mathrm{dS} / \mathrm{m} ; 1.8 \%$ Total $\mathrm{N} ; 0.6 \%$ Total $\mathrm{P} ; 1.6 \%$ Total $\mathrm{K} ; 50 \%$ organic matter; $23.5 \%$ organic carbon; $1: 14.2 \mathrm{C}$ : N; $1 \%$ Sodium chloride; 1650ppm Fe; 82 ppm Cu; $195 \mathrm{ppm} \mathrm{Zn}$. Herbicides were sprayed at the rate of 476 liters water per ha. The experimental unit of the sub-plot area was $3.5 \times 3 \mathrm{~m}$. The experiments were preceded by maize in both seasons. Faba bean (Vicia faba) cv. Giza 843 was grown in the soil described previously. Faba bean seeds were inoculated with the specific Rhizobium strain and immediately sown in hills $25 \mathrm{~cm}$ apart, on both sides of the ridge during the two growing seasons. Conventional cultural faba bean plant practices were followed, especially irrigation. Harvesting was on the $26^{\text {th }}$ and $28^{\text {th }}$ of April in the first and second seasons, respectively.

At 60 DAS, weed samples from one square meter were randomly taken from each plot during both seasons. Weeds were identified and classified as broodleaves, grasses and total weeds. Dry weight of weeds was estimated after drying in a forced draft oven at $70{ }^{\circ} \mathrm{C}$ for $72 \mathrm{hrs}$. Common weeds in both growing seasons were: Wild beet (Beta vulgaris L.), Greater ammi (Ammi majus L.), Dock (Rumex dentatus L.), Bur clover (Medicago hispida L.), Annual yellow sweetclover (Melilotus indicus L.), Wild oat (Avena fatua L.), Ryegrass (Lolium temulentum L.), Bermudagrass (Cynodon dactylon L.), and Purple nutsedge (Cyperus rotundus L.).

Ten plants were selected at random from the inner rows of each sub-plot at 60 and 90 days after sowing to determine the relative growth rate and its components. At each time, plants were excised at ground level for separation into above ground (leaves, stems and reproductive organs) and below ground portions (roots). To remove soil particles and plant debris from the root surface, the below ground portion was washed carefully under tap water. Leaves, stems, reproductive organs and roots were oven-dried at $70^{\circ} \mathrm{C}$ for $72 \mathrm{hrs}$ and their dry weights were measured. Leaf areas 
were measured for each plant by applying the disk method. Plant growth was evaluated based on the estimated relative growth rate (RGR), and its components, net assimilation rate (NAR), specific leaf area (SLA) and leaf weight ratio (LWR) by the interval method from 60 (T2) to 90 DAS (T2). RGR, NAR, LWR, and SLA were calculated in the two harvests according to Hunt (1982) as follows:

\section{Relative growth rate (RGR) was factorized as follows:}

$$
R G R=\text { NAR } x \text { SLA } x \text { LWR }
$$

Net assimilation rate $(\mathrm{NAR})=\frac{\mathrm{Ln} A 2-\mathrm{Ln} A 1}{\mathrm{~A} 2-\mathrm{A} 1} \times \frac{\mathrm{W} 2-\mathrm{W} 1}{\mathrm{~T} 2-\mathrm{T} 1}$

where, NAR $\left(\mathrm{mg} \mathrm{cm}^{-2} \mathrm{w}^{-1}\right)$ is the net dry matter productivity per unit leaf area per unit time. $\mathrm{A}$ is leaf area, $\mathrm{W}$ is total dry matter and $\mathrm{T}$ is time.

Specific leaf area $(\mathrm{SLA})=\frac{(\mathrm{A} 1 / \mathrm{W} 1)+(\mathrm{A} 2 / \mathrm{W} 2)}{2}$

where SLA $\left(\mathrm{cm}^{2} \mathrm{~g}^{-1}\right)$ is leaf area per unit leaf weight.

Leaf weight ratio $(L W R)=$

$\frac{[\text { leaf DW (1) / total DW (1)] + [leaf DW (2) / total DW (2)] }}{2}$

where LWR (dimensionless) is the ratio of leaf dry weight to plant dry weight.

At faba bean plant harvest, plant height, number of branches per plant, number of pods per plant, pod weight per plant (g), number of seeds per pod, number of seeds per plant, seed yield per plant (g), biological yield per plant (g), seed yield per ha $(\mathrm{kg})$, and seed index (SI ) were estimated. Seed yield per ha $(\mathrm{kg})$ was estimated based on seed weight per plot adjusted to $15 \%$ moisture. Protein percentage was determined according to AOAC. (1980).

Regular analysis of variance was performed for each trait in both seasons and the combined analysis over seasons after testing error variance homogeneity was carried out according to the procedure outlined by Gomez \& Gomez (1984), using the MSTATC version 2.1 (Michigan State University, USA) statistical package design. Significant differences between the treatments were compared with the critical difference at $5 \%$ probability by LSD.

\section{RESULTS AND DISCUSSION}

\section{Weed growth:}

Dry weight (DW) of broadleaves, grasses and total weeds increased significantly by applying the organic and NPK fertilizer mixture, compared to the control (Table 1). The nonweeded treatment scored the highest significant dry weight value for broadleaves, grasses and total weeds, while hand hoeing twice scored the lowest value of all weed species. However, hand hoeing, mainly hand hoeing twice and hand hoeing once plus oxadiargyl and hand hoeing once plus prometryn presented the best weed dry weight (DW) control. Table (1) data showed that the weed control treatments under the investigation significantly decreased to a certain extent the dry weight of broadleaved weeds, compared to the non-weeded check at 60 days after sowing (DAS). The highest efficiency in broadleaved weed dry weight decrease was obtained by hand hoeing twice, followed by oxadiargyl plus hand hoeing once, prometryn plus hand hoeing once, oxadiargyl and prometryn. The highest effectiveness of hand hoeing, oxadiargyl and prometryn treatments against faba bean broadleaved weeds could be attributed to the high susceptibility of this weed to both hand hoeing and the herbicidal activity of these herbicides. Metwally (2002), Saad E1-Din (2003) and Sharara et al. (2005) also reached the same conclusion.

Table 1 shows that dry weight of grassy weeds at 60 DAS was significantly reduced by all weed control treatments compared with the non-weeded treatment in the combined analysis of the two seasons. The results also indicated that oxadiargyl + one hand hoeing gave the best control compared to the other weed control treatments. It reduced dry weight 
of grassy weeds as compared to the nonweeded check by $83.7 \%$. Treatments of two hand hoeings, prometryn + one hand hoeing, oxadiargyl and prometryn were very effective in controlling most grassy weeds at 60 DAS. These results may be due to the inhibition effect of the herbicidal treatments on weed growth. The current results are in agreement with those obtained by Nikolova \& Baeva (2000) and Abd El-Razik (2006).

All weed control treatments resulted in significant reduction of dry weight of total weeds (Table 1). The results also indicated that hand hoeing twice provided the best weed control, compared to other weed control treatments. It reduced dry weight of total weeds as compared to non-weeded check by $90.7 \%$. Regarding the herbicidal treatments, the highest efficiency in decreasing dry weight of total weeds was obtained by oxadiargyl plus one hand hoeing, prometryn plus one hand hoeing, oxadiargyl and prometryn treatments, respectively. These treatments reduced dry weight of total weeds as compared to nonweeded treatments by $87.4,80.7,75.1$ and $66.1 \%$, respectively, while the non-weeded treatment resulted in the highest dry weight values for total weeds. Figure 1 results show the interaction between fertilizers and the weed control treatments on dry weight of total

Table 1 - Combined main effects of fertilizers and weed control treatments on dry weights of broadleaved, grasses and total weeds associated with faba bean $\left(\mathrm{g} \mathrm{m}^{-2}\right)$ at $60 \mathrm{DAS}$

\begin{tabular}{|c|c|c|c|}
\hline & $\begin{array}{c}\text { DW } \\
\text { broadleaves } \\
\left(\mathrm{g} \mathrm{m}^{-2}\right)\end{array}$ & $\begin{array}{c}\text { DW } \\
\text { grasses } \\
\left(\mathrm{g} \mathrm{m}^{-2}\right)\end{array}$ & $\begin{array}{c}\text { Total } \\
\text { DW } \\
\left(\mathrm{g} \mathrm{m}^{-2}\right)\end{array}$ \\
\hline \multicolumn{4}{|l|}{ Fertilizer: } \\
\hline Compost & 379.8 & 83.3 & 463.1 \\
\hline Compost $+100 \%$ NPK & 478.1 & 101.5 & 579.6 \\
\hline Compost $+50 \%$ NPK & 426.6 & 77.6 & 504.2 \\
\hline $100 \%$ NPK & 471.9 & 93.8 & 555.7 \\
\hline Control & 353.9 & 62.9 & 416.8 \\
\hline $\mathrm{LSD}_{0.05}$ & 28.9 & 5.2 & 31.2 \\
\hline \multicolumn{4}{|l|}{ Weed c ontrol: } \\
\hline Oxadiargyl & 315.3 & 60.1 & 375.4 \\
\hline Prometryn & 388.3 & 121.5 & 509.8 \\
\hline Oxadiargyl + one hand hoeing & 159.7 & 29.6 & 189.3 \\
\hline Prometryn + one hand hoeing & 235.6 & 56.0 & 291.6 \\
\hline Two hand hoeing & 98.0 & 42.0 & 140.0 \\
\hline Control & 1323.3 & 181.7 & 1505.0 \\
\hline $\mathrm{LSD}_{0.05}$ & 31.7 & 5.7 & 34.2 \\
\hline
\end{tabular}

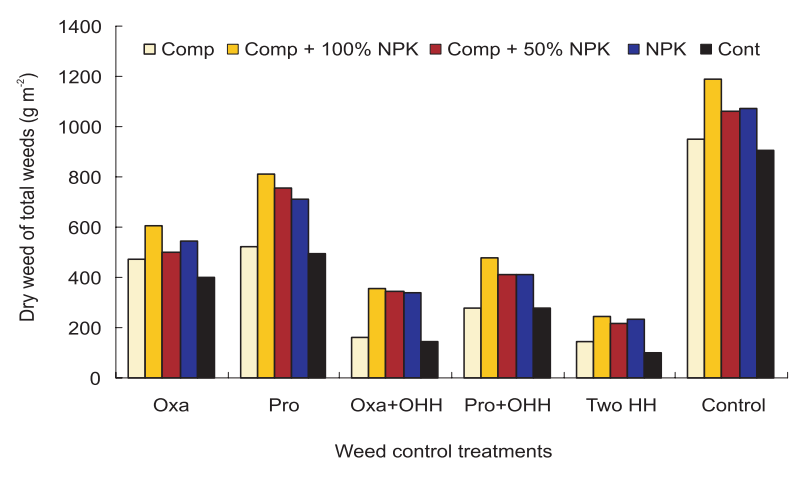

Figure 1 - Combined main effects of interaction among five fertilizers (compost, compost $+100 \%$ NPK, compost + $50 \%$ NPK, $100 \%$ NPK and non-fertilized as control) and six weed control treatments (oxadiargyl, prometryn, oxadiaegyl + one hand hoeing, prometryn + one hand hoeing, two hand hoeings and non-weeded as control) on dry weight of total weeds $\left(\mathrm{g} \mathrm{m}^{-2}\right)$, associated with faba bean crop at 60 DAS.

weeds $\left(\mathrm{g} \mathrm{m}^{-2}\right)$. Addition of compost $+100 \%$ NPK markedly produced the highest dry weight of total weeds in non-weeded subplots.

These results may be due to the inhibition and deleterious effect of herbicidal treatments on weed growth, coinciding with the findings of Saad El Din (2003), Sha et al. (2004), Singh \& Jolly (2004), and Abd El-Razik (2006). Weed growth increase under the fertilizer treatments (compost alone, compost plus NPK or NPK alone), may be attributed to the releasing of $\mathrm{N}, \mathrm{P}$ and $\mathrm{K}$ and other elements, with improved physical and chemical characteristics of the soil consequently improving weed growth.

\section{Faba bean growth}

Relative growth rate (RGR) and its components, NAR, SLA and LWR for faba bean plants under five fertilizer treatments and six weed control treatments are shown in Table 2. RGR significantly increased with all fertilizer treatments, compared to the control. This increase was due to LWR increase only. Compost application at the rate of $10 \mathrm{t} \mathrm{ha}^{-1}$ plus $100 \%$ NPK gave the greatest values of relative growth rate (Table 2). This result confirmed the previous ones obtained by Abdelhamid et al. (2004), who reported that using compost at a rate of $10 \mathrm{tha}^{-1}$ is sufficient to obtain good faba bean growth and yield compared to the control. These authors also reported that using compost or organic 
Table 2 - Combined main effects of fertilizers and weed control treatments on net assimilation rate (NAR), specific leaf area (SLA), leaf weight ratio (LWR) and relative growth rate (RGR) of faba bean plants within 60-90 DAS

\begin{tabular}{|c|c|c|c|c|}
\hline & $\operatorname{NAR}\left(\mathrm{mg} \mathrm{cm}^{-2} \mathrm{w}^{-1}\right)$ & $\operatorname{SLA}\left(\mathrm{cm}^{2} \mathrm{mg}^{-1}\right)$ & LWR & $\operatorname{RGR}\left(\mathrm{mg} \mathrm{mg}^{-1} \mathrm{w}^{-1}\right)$ \\
\hline \multicolumn{5}{|l|}{ Fertilizer: } \\
\hline Compost & 3.887 & 0.344 & 0.358 & 0.479 \\
\hline Compost $+100 \%$ NPK & 3.788 & 0.357 & 0.365 & 0.494 \\
\hline Compost $+50 \%$ NPK & 3.906 & 0.350 & 0.353 & 0.483 \\
\hline $100 \%$ NPK & 3.946 & 0.355 & 0.348 & 0.487 \\
\hline Control & 3.889 & 0.352 & 0.331 & 0.453 \\
\hline $\mathrm{LSD}_{0.05}$ & NS & NS & 0.007 & 0.030 \\
\hline \multicolumn{5}{|l|}{ Weed control: } \\
\hline Oxadiargyl & 3.922 & 0.352 & 0.345 & 0.476 \\
\hline Prometryn & 4.045 & 0.345 & 0.339 & 0.473 \\
\hline Oxadiargyl + one hand hoeing & 4.048 & 0.341 & 0.349 & 0.482 \\
\hline Prometryn + one hand hoeing & 3.824 & 0.360 & 0.355 & 0.489 \\
\hline Two hand hoeings & 4.045 & 0.361 & 0.363 & 0.530 \\
\hline Control & 3.559 & 0.332 & 0.336 & 0.397 \\
\hline $\mathrm{LSD}_{0.05}$ & 0.303 & NS & 0.007 & 0.033 \\
\hline
\end{tabular}

materials resulted in the release of $\mathrm{N}, \mathrm{P}$ and $\mathrm{K}$ and other elements improving the physical and chemical characteristics of the soil and consequently resulting in improved faba bean growth and yield.

All weed control treatments, independently of the method evaluated, significantly increased NAR and LWR but not SLA, resulting in improved RGR (Table 2). The highest RGR values were found by using hand hoeing alone as two hand hoeing and one hand hoeing plus oxadiargyl and prometryn plus one hand hoeing treatments. These findings may be due to the role those treatments play in controlling weeds. Thus, competition was consequently limited in this situation, with more light, water and nutrients being available to promote faba bean growth, compared to the other treatments. These results agree with those presented by Ramadan \& Saad E1-Din (2002).

\section{Faba bean yield and its attributes}

Highest plants were obtained under all fertilizer treatments compared to the control (Table 3). Branch number per plant and seed number per pod were not significantly affected by the fertilizer treatments. The highest values of pod number per plant, pod weight per plant, seed yield per plant, biological yield per plant, total crude protein \% of seeds were obtained under compost combined with NPK (50 and 100\% of NPK) and recommended dose of NPK. The highest values of seed yield obtained with compost + 100\% NPK, 100\% NPK, compost $+50 \%$ NPK and compost, respectively. The increases reached 68.7, 50.7, 43.1 and $36.7 \%$ average of two seasons over the nonfertilized treatment. Harvest index (HI) was calculated as seed yield per plant to biological yield per plant. HI scored the highest percentage with compost alone and NPK. Seed yield ( $\left.\mathrm{kg} \mathrm{ha}^{-1}\right)$ significantly increased under all fertilizer treatments compared to the control. Compost combined with NPK and NPK alone scored the highest values.

Table 3 data indicate that plant height $(\mathrm{cm})$ at harvest, number of pods per plant, plant pod weight (g) and number of seeds per plant were significantly increased compared to the non-weeded treatments, as a result of controlling weeds by different treatments. The highest values were obtained by hand hoeing twice, followed by one hand hoeing plus oxadiargyl, one hand hoeing plus prometryn, oxadiargyl and prometryn. No significant differences were found among the treatments in number of branches per plant and number of seed per pod. All weed control treatments resulted in reduction of TCP $\%$, when compared 


\begin{tabular}{|c|c|c|c|c|c|c|c|c|c|c|c|c|c|c|c|}
\hline 它 & 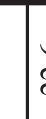 & \begin{tabular}{l|l}
0 & \\
ì & \\
&
\end{tabular} & $\vec{i}$ & 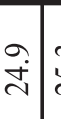 & 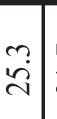 & $\overrightarrow{\dot{v}}$ & $\begin{array}{l}0 \\
0 \\
0 \\
0\end{array}$ & & $\stackrel{\vec{v}}{\tilde{\lambda}}$ & $\begin{array}{l}n \\
\vec{i} \\
\end{array}$ & $\begin{array}{l}\infty \\
2 \\
2 \\
\end{array}$ & $\begin{array}{l}0 \\
\stackrel{+}{\sim}\end{array}$ & $\stackrel{+}{\stackrel{\sim}{~}}$ & ठे. & ลे \\
\hline 目 & 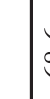 & \begin{tabular}{l|l}
0 \\
0 \\
0 \\
0 & 5 \\
\end{tabular} & $\begin{array}{l}m \\
3 \\
6\end{array}$ & \begin{tabular}{l|l}
$\tilde{B}$ & $y$ \\
$\tilde{8}$ & 4
\end{tabular} & $\overline{8}$ & $\vec{d}$ & $\stackrel{m}{m}$ & & \begin{tabular}{|l}
0 \\
8 \\
\end{tabular} & हु. & $\begin{array}{l}- \\
\infty \\
\infty\end{array}$ & $\ddot{8}$ & 尔 & ก. & $\ddot{m}$ \\
\hline 离 & ई & \begin{tabular}{c|c}
0 \\
0 \\
0 \\
0 & 0 \\
0 & 0 \\
0
\end{tabular} & $\vec{\sigma}$ & \begin{tabular}{l|l}
1 & \\
0 & 0 \\
0 & 0 \\
0 & 0
\end{tabular} & $\begin{array}{c}\mathbb{1} \\
\infty \\
0 \\
0\end{array}$ & 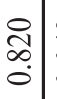 & 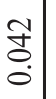 & & $\mid \begin{array}{c}n \\
\infty \\
0 \\
0 \\
0\end{array}$ & $\mid \begin{array}{l}0 \\
⿱ \\
\infty \\
0 \\
0\end{array}$ & $\mid \begin{array}{c}2 \\
\infty \\
0 \\
0\end{array}$ & 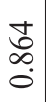 & 点 & $\frac{\pi}{2}$ & 象 \\
\hline 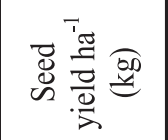 & 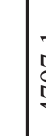 & $\frac{1}{8}$ & $\begin{array}{l}a \\
\check{n} \\
\check{n} \\
\end{array}$ & 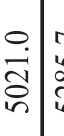 & 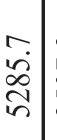 & $\begin{array}{l}a \\
\vdots \\
\vdots \\
n \\
m\end{array}$ & $\begin{array}{c}n \\
\stackrel{2}{n}\end{array}$ & & 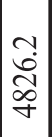 & $\begin{array}{l}0 \\
\dot{0} \\
\dot{d} \\
o\end{array}$ & 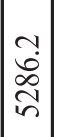 & 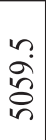 & $\begin{array}{l}\infty \\
\tilde{\pi} \\
\delta \\
\delta\end{array}$ & ๙ิे & 过 \\
\hline 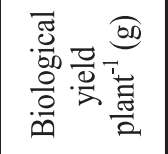 & & $\begin{array}{l}0 \\
\dot{b} \\
\end{array}$ & $\begin{array}{l}\dot{+} \\
\dot{\infty}\end{array}$ & 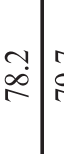 & $\overrightarrow{2}$ & $\begin{array}{l}\infty \\
\dot{\sim} \\
\dot{n}\end{array}$ & $\stackrel{\infty}{i}$ & & $\vec{\infty}$ & $\begin{array}{l}\overrightarrow{0} \\
\infty \\
i\end{array}$ & $\mid \begin{array}{c}n \\
\infty \\
\infty \\
\infty\end{array}$ & $\stackrel{n}{\sim}$ & $\stackrel{\infty}{0}$ & $\ddot{n}$ & $\bar{m}$ \\
\hline 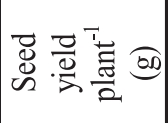 & & $\begin{array}{l}\dot{f} \\
\dot{f}\end{array}$ & $\dot{n}$ & \begin{tabular}{c|c}
$\vec{\sigma}$ & 0 \\
$\vec{\sigma}$ &
\end{tabular} & $\frac{a}{\dot{m}}$ & $\vec{m}$ & $\stackrel{\infty}{-}$ & & $\begin{array}{l}\dot{0} \\
\dot{y}\end{array}$ & 穴. & $\begin{array}{l}a \\
\tilde{n}\end{array}$ & $\begin{array}{c}-7 \\
\dot{\infty} \\
+\end{array}$ & ச8 & $\stackrel{\vec{\sim}}{\stackrel{\sim}{\sim}}$ & $\stackrel{\circ}{i}$ \\
\hline 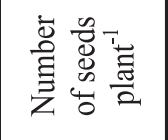 & & $\stackrel{8}{n}$ & 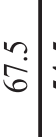 & 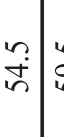 & $\begin{array}{l}n \\
n \\
n\end{array}$ & $\begin{array}{l}\infty \\
\stackrel{\sim}{f}\end{array}$ & $\begin{array}{l}\underset{0}{\sim} \\
\stackrel{i}{ }\end{array}$ & & $\vec{i}$ & $\overrightarrow{⿱ 宀}$ & $\ddot{8}$ & 点 & $\begin{array}{l}\infty \\
\infty \\
\infty \\
\infty\end{array}$ & & $\stackrel{\infty}{\sim}$ \\
\hline 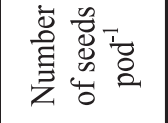 & i & $\begin{array}{c}\infty \\
\end{array}$ & $\overrightarrow{+}$ & $\stackrel{\vec{m}}{\vec{m}}$ & $\stackrel{\circ}{+}$ & $\dot{m}$ & 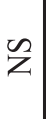 & & $\vec{m}$ & \begin{tabular}{|}
0 \\
$\dot{r}$
\end{tabular} \mid & $\stackrel{\sim}{\underset{\sim}{*}}$ & $\stackrel{\check{m}}{.}$ & $\stackrel{\sim}{f}$ & $\stackrel{\sigma}{\sigma}$ & $\bar{z}$ \\
\hline 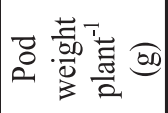 & & 8 & త్ర & 灾 & ָָ. & $\begin{array}{c}a \\
\infty \\
m\end{array}$ & $\vec{i}$ & & $\exists$ & $\stackrel{+}{\dot{q}}$ & త్ & 咅 & 7 & ন্ं & $\stackrel{n}{i}$ \\
\hline 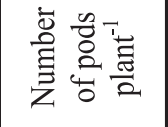 & & $\stackrel{2}{a}$ & 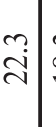 & $\begin{array}{c}m \\
\infty \\
\infty\end{array}$ & ָֻ. & $\stackrel{\sim}{\underline{\Xi}}$ & $=$ & & $\begin{array}{l}\infty \\
\stackrel{\infty}{n}\end{array}$ & $\stackrel{+}{\dot{\Xi}}$ & $\exists$ & $\begin{array}{l}\infty \\
\infty \\
\infty\end{array}$ & $\underset{\stackrel{+}{\sim}}{ }$ & $\cong$ & $\cong$ \\
\hline 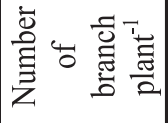 & & $\dot{m}:$ & 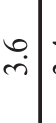 & $\stackrel{\nabla}{\dot{r}}$ & $\vec{m}$ & $\stackrel{\circ}{\dot{m}}$ & $\tilde{Z}$ & & $\overrightarrow{\mathrm{i}}$ & $\underset{n}{n}$ & $\stackrel{m}{m}$ & $\begin{array}{l}0 \\
\text { ri }\end{array}$ & $\stackrel{\circ}{+}$ & $\stackrel{+}{i}$ & $\bar{z}$ \\
\hline 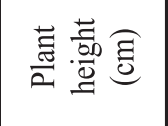 & & â & $\begin{array}{c}\tilde{i} \\
\tilde{a}\end{array}$ & 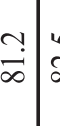 & $\begin{array}{l}\tilde{n} \\
i \\
\infty\end{array}$ & ָৃ๐ & $\stackrel{\circ}{i}$ & & $\begin{array}{l}0 \\
\dot{\infty} \\
\end{array}$ & $\begin{array}{l}n \\
\stackrel{n}{R} \\
-1\end{array}$ & $\begin{array}{c}a \\
\infty \\
\infty\end{array} \mid$ & $\begin{array}{c}\infty \\
\infty \\
\infty\end{array}$ & $\begin{array}{l}\infty \\
\text { à }\end{array}$ & शे & $\approx$ \\
\hline & : & | & 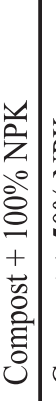 & 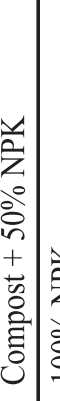 & 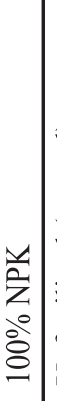 & 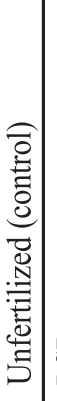 & 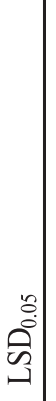 & 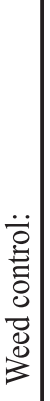 & 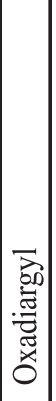 & 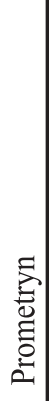 & 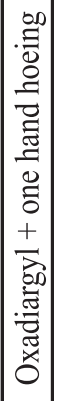 & 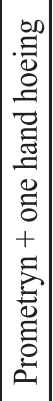 & 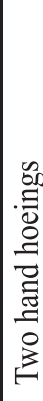 & (0) & $\mid$ \\
\hline
\end{tabular}


to two hand hoeing treatments and the lowest values were obtained under non-weeded treatments. Hand hoeing treatments, mainly two hand hoeings, one hand hoeing plus oxadiargyl or prometryn, oxadiargyl and prometryn provided the highest $(\mathrm{p} \leq 0.05)$ seed yield values $\left(\mathrm{kg} \mathrm{ha}^{-1}\right)$. They significantly increased seed yield per ha over the nonweeded check by $70.9,49.2,42.8,36.2$ and $31.7 \%$, respectively. The superiority of these treatments in producing high seed yield may be due to their high efficiency in controlling a broad spectrum of weeds without damaging faba bean plants. This may reduce weed competitive capacity, leading to increased seed yield. Improved impact of effective hand hoeing and herbicide on faba bean seed yield was also reported by Soliman et al. (1998) and Singh \& Jolly (2004).

Results indicated that there was a significant interaction between fertilizers and the weed control treatments on seed yield $\left(\mathrm{kg} \mathrm{ha}^{-1}\right)$, as illustrated in Figure 2. The highest values of seed yield were recorded when faba bean was fertilized with compost + $100 \%$ NPK and two hand hoeings. Addition of organic manure alone and/or mixed with the chemical fertilizer for faba bean plants enhanced root system absorption of the mineral released from compost decomposition, favoring growth and yield. The superiority of two hand hoeing treatments in producing high

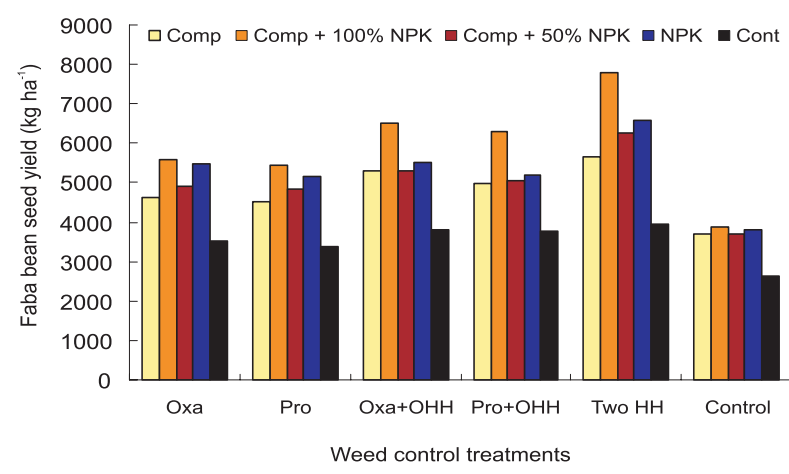

Figure 2 - Combined main effects of interactions among five fertilizers (compost, compost $+100 \%$ NPK, compost + $50 \%$ NPK, $100 \%$ NPK and non-fertilized as control) and six weed control treatments (oxadiargyl, prometryn, oxadiaegyl + one hand hoeing, prometryn + one hand hoeing, two hand hoeings and non-weeded as control), on faba bean seed yield $\left(\mathrm{kg} \mathrm{ha}^{-1}\right)$ at harvest seed yield may be due to their efficiency in controlling weeds without damaging faba bean plants. On the other hand, the lowest seed yield values $\left(\mathrm{kg} \mathrm{ha}^{-1}\right)$ were obtained in the nonfertilized and non-weeded treatments. It can be generally stated that the treatments hand hoeing, oxadiargyl and prometryn reduced the dry weight of weeds grown with faba bean plant (Table 1) and minimized weed-faba bean plant competition, consequently increasing faba bean plants' capacity of utilizing environmental factors, such as light, mineral nutrients and water to build a large amount of metabolites for new tissues. This may account for the previous finding. Similar results were reported by Metwally (2002), Saad E1-Din (2003), Sharara et al. (2005) and Abd El-Razik (2006).

It can be concluded that Vicia faba is one of the leguminous plants whose need of nitrogen fertilizer is little compared with other vegetable crops. At the same time, it is known that nitrogen release as well as that of other elements from compost is slow. This means that the amount of available nitrogen for plant absorption is just what the faba bean plant requires. Thus, when organic nitrogen was applied alone, seed yield was less than when mixed with chemical nitrogen. Chemicals fertilizers combined with organic chemical promote microorganism activity over the organic materials to release the mineral elements. The same conclusion was reached by Zeidan et al. (2001), Ahmed et al. (2003), and Mohamed et al. (2004) working on faba bean, Sinaj et al. (2002) and El-Sedfy et al. (2003) on clover and Fanous et al. (2003) on peanut.

In sum, application of compost alone or combined with 50 or $100 \%$ of the recommended NPK dose improved faba bean growth in terms of net assimilation rate, specific leaf area, and leaf weight ratio, as components of relative growth rate. This improvement in growth resulted in increased seed yield, yield components and protein of faba bean. Hand hoeing treatments, mainly two hand hoeings, followed by one hand hoeing plus oxadiargyl, one hand hoeing plus prometryn, oxadiargyl and prometryn treatments scored the highest $(\mathrm{p} \leq 0.05)$ values of faba bean seed yield $\left(\mathrm{kg} \mathrm{ha}^{-1}\right)$. Faba bean yield performance improved under interactive effects of fertilizer and weed 
control treatments as growth improved, as result of nutrient release from fertilizers and weed control.

\section{LITERATURE CITED}

ABDELHAMID, M.; HORIUCHI, T.; OBA, S.

Composting of rice straw with oilseed rape cake and poultry manure and its effects on faba bean (Vicia faba L.) growth and soil properties. Biores. Technol., v. 93, n. 2, p. 183189, 2004.

ABD EL-RAZIK, M. A. Effect of some weed control treatments on growth, yield, yield components and some seed technological characters and associated weeds of faba bean plants. J. Agric. Sci. Mansoura Univ., v. 31, n. 10, p. 6283-6292, 2006.

AHMED, M. K. A.; AFIFI, M. H.; MOHAMED, M. F. Effect of biofertilizers, chemical and organic fertilizers on growth, yield and quality of some leguminous crops. Egypt. J. Agron., v. 25, n. 1, p. 45-52, 2003.

A.O.A.C. Official methods of analysis of the association official analytical chemist. $13^{\text {th }}$ ed. Washington, D.C., U.S.A., 1980. Disponible in: $<$ ?xml:namespace prefix $=$ o ns ="urn:schemas-microsoft-com:office:office" $>$.

DICKMANN, R. et al. Oxadiargyl: a novel herbicide for rice and sugarcane. BRIGHTON CROP PROTECTION CONFERENCE WEEDS, 1997, Brighton. Proceeding of an International Conference. Brighton: 1997. v. 1, p. 51-57.

EDMEADES, D. C. The long-term effects of manures and fertilizers on soil productivity and quality: a review. Nutr. Cycl. Agroecosys., v. 66, p. 165-180, 2003.

EL-SEDFY, O. M. F. et al. Residual effect of different organic materials on some physical properties of sandy soil production and nutrient content of Egyptian clover. J. Agric. Sci. Mansoura Univ., v. 28, n. 8, p. 6505-6515, 2003.

FANOUS, N. E.; ABD EL-RASOUL, SH. M.; HASSAN, M. M. Sustainable peanut production through integration between bioorganic and chemical fertilizers. J. Agric. Sci. Mansoura Univ., v. 28, n. 5, p. 4243-4258, 2003.

FERNANDES, J. D. Weed control in faba bean proceeding of the $4^{\text {th }}$ EWRS symposium on weed problems in Mediterranean climates. Problems of weed control in fruit, horticultural crops and rice, Valentia, Spain, 1989. v. 2, p. 83-88, 1989.

GOMEZ, K. A.; GOMEZ, A. A. Statistical procedures for agricultural research. $2^{\text {nd }}$ Editon, Singapore: John Wiley \& Sons Inc., 1984. 680 p.
HAMAIL, A. FL; HELALIA, A. M.; GHALY, F. M. Effect of nitrophoska and sagral fertilizers on growth and yield common bean (Phaseolus vulgaris L.). J. Agric. Sci., Mansoura Univ., v. 21, n. 1, p. 351-360, 1996.

HUNT, R. Plant growth curves: The functional approach to plant growth analysis. London, Edward Arnold, 1982. p. $14-46$.

MAHMOUD, A. R.; HAFEZ, M. M.; ABD EL-AAL, F. S. Comparative study for using organic manure as individual and/or mixing it with chemical fertilizer and their effects on the productivity of Vicia faba plants. J. Agric. Sci., Mansoura Univ., v. 29, n. 3, p. 1345-1354, 2004.

METWALLY, G. M. Influence of herbicidal weed control treatments on weed growth, nutrient uptake, yield and yield components of faba bean (Vicia faba L.). J. Agric Sci., Mansoura Univ., v. 27, n. 4, p. 2185-2196, 2002.

NIKOLOVA, V.; BAEVA, G. Effect of oxadiargyl on the weeds of Allium cepa L. and soil biological activity. Bulg. J. Agric. Sci., v. 6, n. 5, p. 533-537, 2000.

PHONGPAN, S.; MOSIER A. R. Impact of organic residue management on nitrogen use efficiency in an annual rice cropping sequence of lowland central Thailand. Nutr. Cycl. Agroecosyst., v. 66, p. 233-240, 2003.

RAMADAN, A. A.; SAAD EL-DIN, S. A. Physiological response of mungbean plants to phosphorus levels and some weed control treatments. J. Agric. Sci. Mansoura Univ. v. 27, n. 12, p. 7983-7996, 2002.

SAAD, E. M. Effect of some organic manures and microelements on greenhouse cucumber. 1999. $141 \mathrm{p}$. MSc. Thesis, Faculty of Agriculture.

SAAD EL-DIN, S. A. Efficiency of some weed control treatments on growth, yield and its components of broad bean (Vicia faba L.) and associated weeds. Egypt. J. Appl. Sci., v. 18, n. 6B, p. 586-604, 2003.

SHARARA, F. A. A.; MESSIHA, N. K.; AHMED, S. A. Performance of some faba bean cultivars and associated weeds to some weed control treatments. Egypt. J. Appl. Sci., v. 20, n. 4, p. 101-105, 2005.

SHA, H. Z. et al. Test on the efficacy of $40 \%$ emulsifiable concentrate of prometryn and acetochlor against soybean weeds. J. Jilin Agric. Univ., v. 26, n. 4, p. 452-454, 2004.

SINAJ, S.; TRAORE, O.; FROSSARD, E. Effect of compost and soil properties on the availability of compost phosphate for white clover (Trifolium repens L.). Nutr. Cycl. Agroecosyst., v. 62, p. 89-102, 2002. 
SINGH, G; WRIGHT D. Effects of herbicides on nodulation and growth of two varieties of peas (Pism sativum). Acta Agron. Hungarica, v. 50, n. 3, p. 337-348, 2002.

SINGH, G.; JOLLY, R. S. Effect of herbicides on the weed infestation and grain yield of soybean (Glycine max). Acta Agronomica Hungarica, v. 52, n. 2, p. 199-203, 2004.

SOLIMAN, F. S.; SABRA, F. S.; EL-DEEB, S. T. Effect of herbicide combinations on growth, yield and yield components of faba bean (Vicia faba L.). Alexandra J. Agric. Res., v. 43, n. 1, p. 81-93, 1998.
TRACCHI, G.; LOUBIERE, P.; MONTAGNON, M. Oxadiargyl: a novel herbicide for sunflower and vegetables. In: BRIGHTON CROP PROTECTION CONFERENCE WEEDS. Proceeding of an International Conference. Brighton, 1997. v. 2. p. 885-889.

TRACCHI, G.; BALLASSO, G.; MALGI, G. Oxadiargyl: a new herbicide for sunflower and vegetable crops.

Proceedings... Ragusa: 1998. p. 333-338.

ZEIDAN, M.; KABESH, M. O.; SABER, M. S. M Utilisation of biofertilizers in field crop production. 14Effect of organic manuring and biofertlisation on yield composition of two faba bean varieties in a newly reclaimed soil. Egypt. J. Agron., v. 23, n. 1, p. 47-54, 2001. 